\title{
РАЗРАБОТКА ФАРМАЦЕВТИЧЕСКОЙ КОМПОЗИЦИИ НА ОСНОВЕ ПЕПТИДОВ И ЛЕКАРСТВЕННОГО РАСТИТЕЛЬНОГО СЫРЬЯ
}

\author{
О.А. Попова', Н.Д. Бунятян ${ }^{1,2}$, И.П. Ремезова ${ }^{3}$ \\ ${ }^{1}$ ФГБУ «Научный центр экспертизы средств медицинского применения» Минздрава \\ России, 127051, Москва, Петровский бульвар, 8. \\ ${ }^{2}$ ФГАОУ ВО Первый Московский государственный медицинский университет \\ им. И.М. Сеченова Министерства здравоохранения Российской Федерации \\ (Сеченовский университет), 119991, Россия, г. Москва, \\ ул. Большая Пироговская, дом 2, стр. 4. \\ ${ }^{3}$ Пятигорский медико-фармацевтический институт - филиал ФГБОУ ВО ВолгГМУ \\ Минздрава России, 357500, Россия, г. Пятигорск, пр. Калинина, 11
}

DOI: 10.19163/MedChemRussia2021-2021-297_ndbun@mail.ru, i.p.remezova@pmedpharm.ru

Разработка новых фармацевтических композиций на основе пептидов и лекарственного растительного сырья является актуальным направлением в развитии современной фармацевтической промышленности и медицины в целом. Растения рода Ferula проявляют широкий спектр фармакологической активности, который обеспечивает большое количество соединений различных классов [1, 2]. Имеется множество новых официальных данных о фармакологической активности камеде-смолы ферулы: антиоксидантной, антилейшманиозной, противораковой, антиконвульсантной, антидиабетической, противоспазматической, гипотензивной и антиноцицептивной $[3,4]$.

На основании анализа данных литературы [5-7] мы предположили, что новая фармацевтическая композиция на основе камеде-смолы ферулы ассафоетиды и трипептида с последовательностью аминокислот H-Pro-Ala-Glu-OH может представлять интерес для последующего изучения её фармакологической активности.

В ходе экспериментальных исследований нами получен сухой экстракт камеде-смолы Ferula assafoetida L., а также синтезирован новый трипептид H-Pro-Ala-Glu-OH. Свойства разработанной фармацевтической композиции в настоящее время изучаются.

\section{Литература}

1. Саидова Н.Г., Кодирова Г.Х., Кароматов И.Дж. Лечебное растение ферула вонючая/ Биология и интегративная медицина 2017. №9. С. 58-77.

2. Иманбаева А.А., Сарсенбаев К.Н., Сагындыкова М.С. Анатомическое строение надземных и подземных органов Ferula foetida (Bunge) Regel в природных популяциях Мангистау/ Сибирский экологический журнал.2015. №6. С. 899-908.

3. Bagheri S. M., Mohammadsadeghi H., Dashti-R. M. H., Mousavian S., Aghaei Z. A. Effect of Ferula assa-foetida oleo-gum-resin on renal function in normal Wistar rats/ Indian J Nephrol [serial online]. 2016.V.26. №6. P. 419-422.

4. Mohammadhosseini M., Venditti A., Sarker S.D., Nahar L., Akbarzadeh A. The genus Ferula: Ethnobotany, phytochemistry and bioactivities - A review / Industrial Crops \& Products. 2019. № 129. P. 350-394.

5. Морозов В.Г., Хавинсон В.Х., Малинин В.В. - Пептидные тимомиметики - СПБ., Наука, 2000. -158 c.

6. Холназаров Б.М. Разработка и фармакологическое исследование иммуномодуляторов на основе пептидов и их координационных соединений с ионом железа (II): автореф. дис. докт. фарм. наук: 14.03.06. Белгород, 2018.-51 с.

7. Бобиев Г.М. Препараты на основе иммуноактивного дипептида и его координационных соединений с ионом цинка): автореф. дис. докт.фарм. наук: 14.04.02. М., 2012.- 48 с. 